\title{
Report of the Korean Association of External Quality Assessment Service on Metabolite Testing (2018-2019)
}

\section{Soo-Youn Lee}

Department of Laboratory Medicine \& Genetics, Samsung Medical Center, Sungkyunkwan University School of Medicine, Seoul, Korea

\section{Corresponding author:}

Soo-Youn Lee

Department of Laboratory Medicine \& Genetics, Samsung Medical Center, Sungkyunkwan University School of Medicine, 81 Irwon-ro, Gangnam-gu, Seoul 06351, Korea

Tel +82-2-3410-1834

Fax +82-2-3410-2719

E-mail suddenbz@skku.edu

This is an Open Access article distributed under the terms of the Creative Commons Attribution Non-Commercial License (http://creativecommons.org/licenses/ by-nc/4.0) which permits unrestricted non-commercial use, distribution, and reproduction in any medium, provided the original work is properly cited.
External quality assessment (EQA) trials of conventional newborn screening tests for phenylketonuria, galactosemia, congenital adrenal hyperplasia, maple syrup urine disease, homocystinuria, and congenital hypothyroidism, as well as extended newborn screening tests using tandem mass spectrometry, were performed twice in 2018 and 2019. A total of 44 dried blood spot specimens were analyzed in each trial in 14-16 laboratories. Median, mean, standard deviation, minimum and maximum values, and cut-off values were evaluated for each analyte in the newborn screening tests. The proportion of correct answers was 95\%-100\%. EQA trials for the analyses of methylmalonic acid, vanillylmandelic acid, catecholamines, metanephrines, organic acids, and amino acids were also performed using two or three specimens per trial. A well-designed EQA program and continuous education can help improve the performance of metabolite testing.

(Lab Med Qual Assur 2020;42:10-25)

Key Words External quality assessment, Newborn screening, Tandem mass spectrometry, Amino acid, Organic acid, Metabolite
서론

대한임상검사정도관리협회에서는 1997 년도부터 선천성대사 질환 선별검사에 대한 신빙도조사사업을 시작하여 매년 2회의 신 빙도조사를 시행해오고 있다. 탠덤질량분석기(tandem mass spectrometry, MS/MS)를 이용한 광범위선별검사에 대한 신빙 도조사사업은 2004년도에 예비 신빙도조사를 실시한 이래 2007 년도부터 정규항목으로 포함하여 시행 중이다[1]. 2011년도부 터는 예비 신빙도조사를 거쳐 소변 메틸말론산(methylmalonic acid, MMA)과 바닐만델산(vanillylmandelic acid, VMA), 소 변 유기산 분석을 추가하였고, 2012년도부터는 혈장 아미노산 및 유기산 종목을 추가하였으며, 2014년도에는 요중 카테콜라민 (catecholamines), 메타네프린(metanephrines) 종목을, 2016
년도부터는 혈중 카테콜라민 및 메타네프린 종목까지 추가하면서 점차 사업대상 종목을 확대해 시행하였다[2-7]. 이에 상기 검사항 목들에 대해 2018년 및 2019년 실시된 총 4회의 신빙도조사결과 를 분석 요약하여 보고하고자 한다.

\section{재료 및 방법}

\section{1. 대상 및 검체}

2018년도 및 2019년도 총 4회의 대사물질검사 신빙도조사대 상항목 및 정도관리 검체 현황은 Table 1 에 정리하였다. 정도관리 검체는 모두 자가제조 검체였으며, 성분별 표준물질 및 상품화된 정도관리물질을 활용하여 준비하였다. 검체 제조에 사용된 표준물 질은 Sigma-Aldrich (St. Louis, MO, USA), Toronto Research 
Table 1. Test items and specimens included in the proficiency tests

\begin{tabular}{|c|c|c|c|c|c|c|}
\hline \multirow{3}{*}{ Test items } & \multirow{3}{*}{ Category } & \multirow{3}{*}{ Specimen } & \multicolumn{4}{|c|}{ No. of specimens } \\
\hline & & & \multicolumn{2}{|c|}{ Year 2018} & \multicolumn{2}{|c|}{ Year 2019} \\
\hline & & & $\begin{array}{l}1 s t \\
\text { trial }\end{array}$ & $\begin{array}{l}\text { 2nd } \\
\text { trial }\end{array}$ & $\begin{array}{c}1 s t \\
\text { trial }\end{array}$ & $\begin{array}{l}\text { 2nd } \\
\text { trial }\end{array}$ \\
\hline \multicolumn{7}{|l|}{ Neonatal screening } \\
\hline \multirow[t]{6}{*}{ Conventional } & Phenylketonuria & DBS & 12 & 12 & 12 & 12 \\
\hline & Congenital hypothyroidism (TSH, T4-total or free) & & 10 & 10 & 10 & 10 \\
\hline & Galactosemia & & 12 & 12 & 12 & 12 \\
\hline & $\begin{array}{l}\text { Congenital adrenal hyperplasia } \\
\text { (17-hydroxyprogesterone) }\end{array}$ & & 12 & 12 & 12 & 12 \\
\hline & Maple syrup urine disease & & 12 & 12 & 12 & 12 \\
\hline & Homocystinuria & & 12 & 12 & 12 & 12 \\
\hline Expanded (by MS/MS) & Approximately 40 inherited metabolic disorders & DBS & 12 & 12 & 12 & 12 \\
\hline Vanillylmandelic acid & & Urine & 3 & 3 & 3 & 3 \\
\hline Methylmalonic acid & & Urine & 3 & 3 & 3 & 3 \\
\hline Organic acids & Approximately 70 organic acids & Urine & 3 & 3 & 3 & 3 \\
\hline Amino acids & Approximately 40 amino acids & Plasma & 2 & 2 & 2 & 2 \\
\hline \multirow[t]{2}{*}{ Catecholamines } & Dopamin, epinephrine, norepinephrine & Urine & 3 & 3 & 3 & 3 \\
\hline & & Plasma & 3 & 3 & 3 & 3 \\
\hline \multirow[t]{2}{*}{ Metanephrines } & Metanephrine, normetanephrine & Urine & 3 & 3 & 3 & 3 \\
\hline & & Plasma & 3 & 3 & 3 & 3 \\
\hline
\end{tabular}

Abbreviations: DBS, dried blood spot; TSH, thyroid-stimulating hormone; T4, thyroxine; MS/MS, tandem mass spectrometry.

Chemicals Inc (North York, ON, Canada), International Laboratory USA (South San Francisco, CA, USA), Crystal Chem USA (Elk Grove Village, IL, USA) 등으로부터 구매하였 다. 또한 Bio-Rad Laboratories (Hercules, CA, USA), Simens Healthcare Diagnositcs Inc. (Tarrytown, NY, USA) 등으로부 터 구매한 보정물질이나 정도관리물질도 검체 제조에 일부 활용하 였다. 모든 신빙도조사 회차별로 항목별 정상과 비정상 수치가 모 두 포함되도록 하였으며, 일부 검체에 대해서는 특정 대사질환에 특이적인 성분 다수를 동시에 포함시켰다. 대사산물검사를 위한 검체들은 냉동상태로 운반되었으며, 각 기관에서 검체를 수령한 즉시 냉동 보관하도록 권고하였다.

기본 선별검사의 대상질환으로는 페닐케톤뇨증(phenylketonuria, PKU), 갈락토오스혈증(galactosemia), 선천성 부신과형성증(congenital adrenal hyperplasia), 단풍당뇨 증(maple syrup urine disease, MSUD), 호모시스틴뇨증 (homocystinuria, $\mathrm{HCY}$ ), 선천성갑상선기능저하증(congenital hypothyroidism) 등 6 가지가 포함되었으며, 총 16 기관을 대상 으로 각 회차별 총 22 개, 연도별 총 44 개의 건조혈액여과지(dried blood spot, DBS) 검체를 발송하였다. MS/MS를 이용한 광범위 선별검사 항목으로 아실카르니틴(acylcarnitine, AC) 및 아미노 산 14종목과 8종의 상대적 비율(ratio)이 포함되었다. DBS 정도 관리 검체는 모두 자가제조하여 준비하였다. DBS 자가제조를 위 해 human immunodeficiency virus 항체와 B형간염 항원이 음 성인 혼합혈청에 식염수로 세척한 $\mathrm{O}$ 형 적혈구 적당량을 첨가하여 헤마토크릿을 약 $55 \%$ 가 되도록 맞춘 전혈을 준비한 후 측정대상 성분에 대한 표준품을 목표한 농도로 첨가하였다. 이를 여과지에 $75 \mu \mathrm{L}$ 씩 분주하여 DBS를 만든 다음 실온의 암실에서 충분히 말린 후 보관하였다.

유기산검사를 위한 소변 검체는 정상 성인의 혼합 소변에 특정 질환에서 대표적으로 상승하는 성분에 대한 표준물질을 고농도로 첨가하여 제조하였다. 혈장 아미노산 분석을 위해서는 정상 성인 의 혼합 혈장(pooled plasma)에 특정 질환에서 대표적으로 상승 하는 아미노산 성분에 대한 표준물질(Sigma-Aldrich)을 첨가한 혈장 검체를 제조하여 발송하였다. 혼합 혈청(pooled serum) 또 는 혼합 소변(pooled urine)에 상품화된 표준물질을 첨가하여 제 조하였다. MMA 및 VMA 신빙도조사 물질로는 정상 성인의 혼합 
소변에 해당 표준물질을 다양한 농도로 첨가하여 각 회차별로 각 각 3 개씩 제조 및 발송하였다. 카테콜라민과 메타네프린 종목 신 빙도조사를 검체들 역시 환자들의 혼합 소변 또는 혈액에 해당 표 준물질을 첨가하여 목표농도로 제조 및 발송하였다.

\section{2. 결과 판정 및 분석}

기본선별검사의 경우에는 각 검사기관이 수행하고 있는 종목에 대해 검사를 실시하여 결과 수치와 함께 정상 및 비정상 여부를 판 정하여 회신하도록 하였다. 검사결과로부터 각 검사기관에서 판독 하는 정상 및 비정상 여부의 판정결과에 대해 분석하였다. MS/MS 를 이용한 광범위선별검사의 경우 $A C$ 및 아미노산 결과 수치와 함 께 정상 및 비정상 여부 판정, 판정기준치(cut-off) 등을 회신하도 록 하였다. 결과분석 시 수치결과에 대해서는 해당 검사방법을 이 용한 응답기관이 3 개 이상인 경우 중앙값, 최소 및 최대값을 제공 하며, 10 개 이상일 경우에 평균, 표준편차, 변이계수를 제공하는 것을 원칙으로 하였다. 결과분석은 응답기관에 대해 판정결과 및 판정일치율과 각 기관에서 사용하고 있는 판정기준치에 대한 평 균, 중앙값, 최저값, 최고값에 대해 분석하였고, 각 기관의 검사성 적에 대한 비교평가 그래프를 제공하였다.

유기산 및 아미노산검사는 소수의 기관만 검사를 수행하므로 측정값을 비교할 수 있도록 각 기관이 보고한 주요 성분에 대한 항 목과 측정값을 제공하였으며, 신빙도조사물질 제조 시 의도한 진 단명을 정답으로 간주하고 각 기관에서 제출한 최종 진단명에 대 하여 정오답 여부를 판정하였다. 기타 정량 결과값에 대해서도 대 부분의 종목이 참여기관 수가 많지 않아 통계분석이 어려우므로, 해당 기관에서 보고한 결과값을 전체 기관 결과값의 중앙값 및 수 치 분포범위를 확인할 수 있도록 하였다. 수탁기관에 대한 정도관
리 인증기준은 참가기관 수 5 개 이상이면서 결과판정 일치율이 $70 \%$ 이상인 기본선별검사 종목을 대상으로, 종목별 보고결과의 정답일치율 $80 \%$ 이상, 참가한 종목 전체 보고결과의 정답일치율 $90 \%$ 이상인 경우이다.

\section{결과}

\section{1. 참여기관 및 회신율}

2018년도 및 2019년도 신빙도조사에서 신생아선별검사 대 상 정도관리물질를 발송한 전체 기관으로부터의 회신율은 $100 \%$ 로 나타났다. 이들 선별검사항목에 대해서 2018년에는 16기관, 2019년 1차에는 15 기관, 2 차에는 14 기관이 신빙도조사에 참여하 였다.

소변VMA검사는 회차별로 6-7개 기관, MMA검사는 4-5개 기 관이 참여하였다. 아미노산검사는 회차별로 5-6개 기관, 유기산 검사는 2-4개 기관이 참여하였다. 카테콜라민과 메타네프린 종목 에 대해서는 각 회차별로 소변과 혈액 검체를 각각 3 개씩 발송하 였으며, 6-7개 기관이 회신하였다.

\section{2. 검사법 및 장비현황}

6 개 질환에 대한 기본 신생아선별검사에 이용되는 검사방법은 Fig. 1과 같았다. 기본선별검사에는 효소비색법, 효소면역측정법, 형광면역법, $\mathrm{MS} / \mathrm{MS}$ 법 등이 이용되어 왔다. 갈락토오스혈증, 선 천성부신과형성증, 선천성갑상선기능저하증 선별검사는 모든 참 여기관에서 면역분석법으로 검사를 시행하고 있다. 한편, $\mathrm{PKU}$, $\mathrm{MSUD}, \mathrm{HCY}$ 선별검사의 경우 현재 모든 기관에서 $\mathrm{MS} / \mathrm{MS}$ 법을, 이외 항목들은 면역분석법을 이용해 검사하고 있는 것으로 나타났

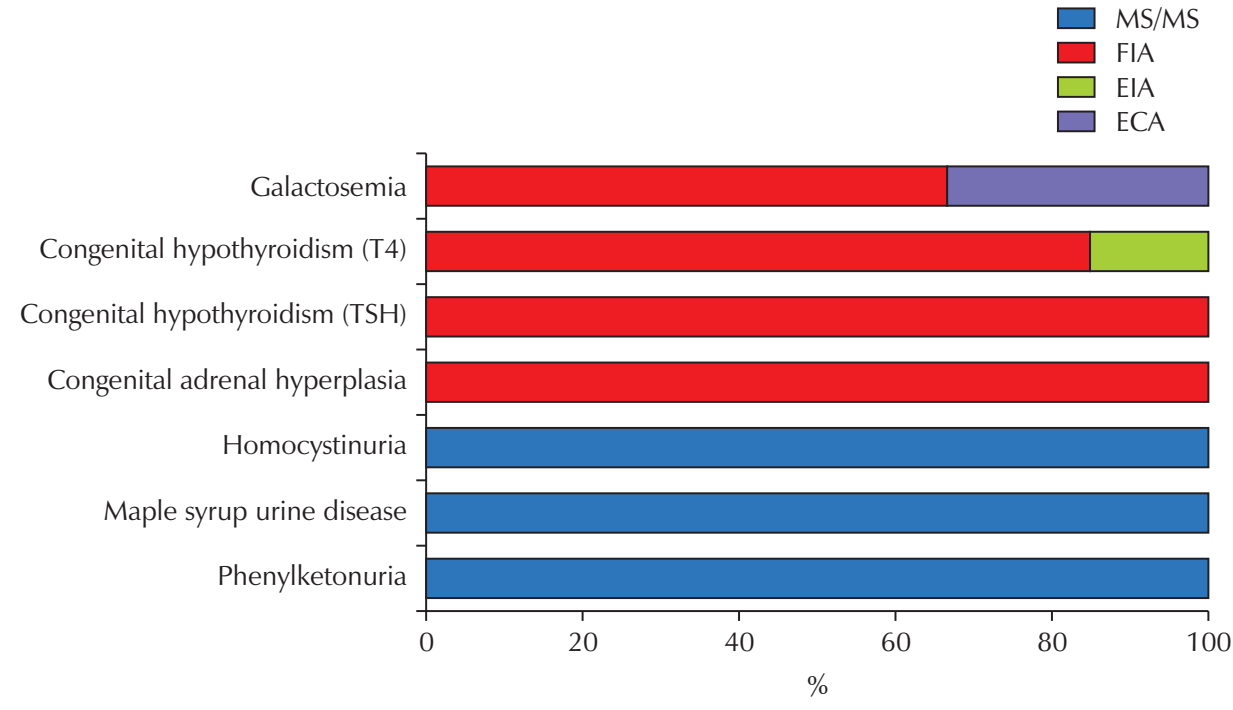

Fig. 1. Analytical methods used for conventional neonatal screening tests of the first trial in 2018. Abbreviations: MS/MS, tandem mass spectrometry; FIA, fluorometric immunoassay using a Perkin-Elmer kit; ECA, enzyme colorimetric assay; EIA, enzyme immunoassay; T4, thyroxine; TSH, thyroid-stimulating hormone. 
다.

VMA, MMA, 유기산검사에는 액체크로마토그래피(liquid chromatography) 또는 액체크로마토그래피-탠덤질량분석법 (liquid chromatography tandem mass spectrometry), 가 스크로마토그래피-질량분석법(gas chromatography-mass spectrometry)이 주로 이용되었으며, 아미노산분석에는 액체크 로마토그래피-탠덤질량분석법 또는 아미노산분석기(amino acid analyzer)가 이용되었다. 요중 및 혈중 카테콜라민과 메타네프린 검사에 있어서는 액체크로마토그래피 또는 액체크로마토그래피탠덤질량분석법이 이용되었다.

\section{3. 신빙도조사결과}

6 종 기본선별검사의 각 항목별 정답률 현황은 Table 2 와 Table 3 에 정리하였다. 선천성갑상선기능저하증 선별검사로 모든 기관 에서 갑상선자극호르몬(thyroid-stimulating hormone, TSH) 을 이용하고 있으며, 2/3 정도의 기관에서는 T4검사를 동시에 시 행하고 있었다. Free T4검사를 시행하는 기관은 2018년도 2개, 2019년도 1 개 기관뿐이었고 이외의 기관에서는 total T4항목을 검사하고 있었다. 갈락토스혈증 선별검사에 있어서 일부 기관에서 다수의 검체에 대한 판정에서 불일치를 보였는데, 전체적으로 낮 은 수치를 보고하면서 비정상 검체를 정상으로 판정하였다. 선천 성부신과형성증 선별검사에 대해서도 1 개 기관에서만 다수의 검 체에 대해 비정상 검체를 정상으로 보고한 것이 판정 불일치를 초

Table 2. Results of the proficiency testing of conventional neonatal screening tests in 2018

\begin{tabular}{|c|c|c|c|c|}
\hline \multirow[b]{2}{*}{ Variable } & \multicolumn{2}{|r|}{ 1st trial } & \multicolumn{2}{|r|}{ 2nd trial } \\
\hline & $\begin{array}{l}\text { No. of } \\
\text { institutions }\end{array}$ & $\begin{array}{c}\text { Proportion of } \\
\text { correct answers (\%) }\end{array}$ & $\begin{array}{l}\text { No. of } \\
\text { institutions }\end{array}$ & $\begin{array}{c}\text { Proportion of } \\
\text { correct answers (\%) }\end{array}$ \\
\hline Phenylketonuria & 16 & $192 / 192(100)$ & 16 & $192 / 192(100)$ \\
\hline Galactosemia & 15 & $168 / 180(95)$ & 15 & $150 / 150(100)$ \\
\hline Congenital adrenal hyperplasia & 14 & $177 / 180(98)$ & 15 & $178 / 180(99)$ \\
\hline Maple syrup urine disease & 15 & $169 / 176(96)$ & 16 & $189 / 192(98)$ \\
\hline Homocystinuria & 15 & 191/192 (99) & 16 & $192 / 192(100)$ \\
\hline \multicolumn{5}{|l|}{ Congenital hypothyroidism } \\
\hline $\mathrm{TSH}$ & 15 & $148 / 150(99)$ & 15 & $150 / 150(100)$ \\
\hline T4, total & 11 & $110 / 110(100)$ & 10 & $89 / 90(99)$ \\
\hline $\mathrm{T} 4$, free & 2 & & 1 & \\
\hline
\end{tabular}

Abbreviations: TSH, thyroid-stimulating hormone; T4, thyroxine.

Table 3. Results of the proficiency testing of conventional neonatal screening tests in 2019

\begin{tabular}{|c|c|c|c|c|}
\hline \multirow[b]{2}{*}{ Variable } & \multicolumn{2}{|r|}{ 1st trial } & \multicolumn{2}{|r|}{ 2nd trial } \\
\hline & $\begin{array}{c}\text { No. of } \\
\text { institutions }\end{array}$ & $\begin{array}{c}\text { Proportion of correct } \\
\text { answers (\%) }\end{array}$ & $\begin{array}{l}\text { No. of } \\
\text { institutions }\end{array}$ & $\begin{array}{c}\text { Proportion of correct } \\
\text { answers (\%) }\end{array}$ \\
\hline Phenylketonuria & 15 & $180 / 180(100)$ & 14 & $168 / 168(100)$ \\
\hline Galactosemia & 14 & $165 / 168(98)$ & 14 & $167 / 168$ (99) \\
\hline Congenital adrenal hyperplasia & 14 & $164 / 168(98)$ & 14 & 166/168 (99) \\
\hline Maple syrup urine disease & 15 & $180 / 180(100)$ & 14 & $168 / 168(100)$ \\
\hline Homocystinuria & 15 & $178 / 180$ (99) & 14 & $168 / 168(100)$ \\
\hline \multicolumn{5}{|l|}{ Congenital hypothyroidism } \\
\hline TSH & 14 & $168 / 168(100)$ & 14 & $168 / 168(100)$ \\
\hline T4, total & 8 & $80 / 80(100)$ & 8 & $79 / 80(99)$ \\
\hline $\mathrm{T} 4$, free & 1 & & 1 & \\
\hline
\end{tabular}

Abbreviations: TSH, thyroid-stimulating hormone; T4, thyroxine. 
Table 4. Cut-off values used in expanded neonatal screening tests using tandem mass spectrometry in the second trial in 2019

\begin{tabular}{|c|c|c|c|c|c|c|}
\hline Variable & Unit & Mean & Median & Minimum & Maximum & $\begin{array}{l}\text { No. of } \\
\text { institu- } \\
\text { tions }\end{array}$ \\
\hline \multicolumn{7}{|l|}{ Amino acids } \\
\hline Alanine & umol/L & 698.2 & 690.8 & 440.1 & 996.0 & 14 \\
\hline Arginine & umol/L & 57.1 & 59.1 & 31.0 & 89.9 & 14 \\
\hline Aspartate & umol/L & & 156.1 & 150.0 & 175.0 & 3 \\
\hline Citrulline & umol/L & 48.0 & 44.7 & 27.8 & 67.9 & 14 \\
\hline Glutamate & umol/L & & 670.1 & 256.7 & 859.7 & 8 \\
\hline Glycine & umol/L & 893.0 & 990.0 & 372.9 & $1,377.7$ & 14 \\
\hline Histidine & umol/L & 249.2 & 184.5 & 58.9 & $1,030.8$ & 12 \\
\hline Leucine+isoleucine & umol/L & 288.5 & 304.5 & 222.0 & 349.1 & 14 \\
\hline Methionine & umol/L & 58.6 & 60.0 & 28.0 & 86.5 & 14 \\
\hline Ornithine & umol/L & 280.2 & 288.0 & 180.0 & 386.9 & 14 \\
\hline Phenylalanine & umol/L & 118.2 & 118.9 & 86.7 & 139.3 & 14 \\
\hline Proline & umol/L & 362.3 & 384.5 & 147.9 & 500.0 & 13 \\
\hline Tyrosine & umol/L & 287.0 & 292.6 & 169.7 & 402.0 & 14 \\
\hline Valine & umol/L & 269.6 & 266.6 & 187.6 & 368.6 & 14 \\
\hline Methionine/phenylalanine & & 1.0 & 1.0 & 0.7 & 1.6 & 10 \\
\hline Phenylalanine/tyrosine & & 2.9 & 2.1 & 1.9 & 8.7 & 10 \\
\hline \multicolumn{7}{|l|}{ Acylcarnitines } \\
\hline $\mathrm{CO}$ & umol/L & 62.47 & 61.03 & 39.70 & 90.00 & 14 \\
\hline $\mathrm{C} 2$ & umol/L & 55.45 & 49.78 & 35.74 & 80.00 & 14 \\
\hline $\mathrm{C} 3$ & umol/L & 5.45 & 5.39 & 3.69 & 6.90 & 14 \\
\hline C4 & umol/L & 0.72 & 0.63 & 0.41 & 1.40 & 14 \\
\hline C5 & umol/L & 0.67 & 0.68 & 0.27 & 1.15 & 14 \\
\hline $\mathrm{C} 6$ & umol/L & 0.28 & 0.22 & 0.10 & 0.52 & 14 \\
\hline $\mathrm{C} 8$ & umol/L & 0.33 & 0.35 & 0.12 & 0.52 & 14 \\
\hline C10 & umol/L & 0.37 & 0.40 & 0.17 & 0.56 & 14 \\
\hline C12 & umol/L & 0.41 & 0.41 & 0.16 & 0.80 & 14 \\
\hline C14 & umol/L & 0.62 & 0.62 & 0.37 & 0.92 & 14 \\
\hline C16 & umol/L & 6.21 & 5.94 & 4.70 & 8.00 & 14 \\
\hline $\mathrm{C} 18$ & umol/L & 1.98 & 1.87 & 1.59 & 2.76 & 14 \\
\hline C5DC & umol/L & 0.28 & 0.30 & 0.14 & 0.35 & 13 \\
\hline $\mathrm{C} 5 \mathrm{OH}$ & umol/L & 0.66 & 0.63 & 0.38 & 1.03 & 12 \\
\hline $\mathrm{C} 3 / \mathrm{C2}$ & & 0.29 & 0.29 & 0.20 & 0.38 & 10 \\
\hline $\mathrm{C} 5 / \mathrm{C} 3$ & & & 0.99 & 0.23 & 2.36 & 9 \\
\hline $\mathrm{C} 8 / \mathrm{C} 10$ & & & 3.28 & 2.14 & 7.18 & 6 \\
\hline $\mathrm{C} 5 / \mathrm{CO}$ & & & 0.03 & 0.02 & 0.06 & 6 \\
\hline $\mathrm{C} 5 / \mathrm{C} 2$ & & & 0.05 & 0.02 & 0.32 & 9 \\
\hline $\mathrm{C} 8 / \mathrm{C} 2$ & & & 0.02 & 0.01 & 0.09 & 9 \\
\hline
\end{tabular}


Table 5. Results of the proficiency testing of expanded neonatal screening tests using tandem mass spectrometry in 2018

\begin{tabular}{|c|c|c|c|c|}
\hline \multirow[b]{2}{*}{ Variable } & \multicolumn{2}{|c|}{ 1st trial } & \multicolumn{2}{|c|}{ 2nd trial } \\
\hline & $\begin{array}{c}\text { No. of } \\
\text { institutions }\end{array}$ & $\begin{array}{c}\text { Proportion of } \\
\text { correct answers (\%) }\end{array}$ & $\begin{array}{c}\text { No. of } \\
\text { institutions }\end{array}$ & $\begin{array}{c}\text { Proportion of } \\
\text { correct answers (\%) }\end{array}$ \\
\hline \multicolumn{5}{|l|}{ Amino acids } \\
\hline Arginine & 16 & 189/192 (98) & 16 & 192/192 (100) \\
\hline Tyrosine & 16 & 174/176 (99) & 16 & $192 / 192(100)$ \\
\hline Phenylalanine & 16 & $192 / 192(100)$ & 16 & $192 / 192(100)$ \\
\hline Methionine & 16 & 191/192 (99) & 16 & 192/192 (100) \\
\hline Citrulline & 16 & 191/192 (99) & 16 & $192 / 192(100)$ \\
\hline Glycine & 16 & $174 / 176$ (99) & 16 & $192 / 192(100)$ \\
\hline Ornithine & 16 & $151 / 160(94)$ & 16 & 179/192 (93) \\
\hline Valine & 16 & $159 / 160(99)$ & 16 & 191/192 (99) \\
\hline Leucine+isoleucine & 16 & $169 / 176(96)$ & 16 & 189/192 (98) \\
\hline Phenylalanine/tyrosine & 16 & 189/192 (98) & 16 & 191/192 (99) \\
\hline Methionine/phenylalanine & 16 & 182/192 (95) & 15 & $180 / 180(100)$ \\
\hline Alanine & 16 & $154 / 160(96)$ & 16 & $192 / 192(100)$ \\
\hline Histidine & 15 & $173 / 180(96)$ & 15 & $180 / 180(100)$ \\
\hline Proline & 15 & $174 / 180(97)$ & 15 & $180 / 180(100)$ \\
\hline Aspartate & 6 & $72 / 72(100)$ & 7 & $84 / 84(100)$ \\
\hline Glutamate & 8 & $72 / 72(100)$ & 9 & $108 / 108(100)$ \\
\hline \multicolumn{5}{|l|}{ Acylcarnitines } \\
\hline $\mathrm{CO}$ & 16 & $168 / 176$ (95) & 16 & $168 / 176$ (95) \\
\hline $\mathrm{C} 2$ & 16 & 192/192 (100) & 16 & 190/192 (99) \\
\hline $\mathrm{C} 3$ & 16 & $176 / 176(100)$ & 16 & $192 / 192(100)$ \\
\hline $\mathrm{C} 4$ & 16 & 188/192 (98) & 16 & $192 / 192(100)$ \\
\hline C5 & 16 & 188/192 (98) & 16 & $192 / 192(100)$ \\
\hline $\mathrm{C} 6$ & 16 & $192 / 192(100)$ & 16 & $192 / 192(100)$ \\
\hline $\mathrm{C} 8$ & 16 & 191/192 (99) & 16 & $192 / 192(100)$ \\
\hline $\mathrm{C} 10$ & 16 & $192 / 192(100)$ & 16 & $192 / 192(100)$ \\
\hline $\mathrm{C} 12$ & 16 & 190/192 (99) & 16 & $187 / 192(97)$ \\
\hline C14 & 16 & 175/176 (99) & 16 & 191/192 (99) \\
\hline C16 & 16 & $191 / 192$ (99) & 16 & $192 / 192(100)$ \\
\hline C18 & 16 & $176 / 176(100)$ & 16 & $192 / 192(100)$ \\
\hline C5DC & 16 & 187/192 (97) & 16 & $192 / 192(100)$ \\
\hline $\mathrm{C} 5-\mathrm{OH}$ & 15 & $180 / 180(100)$ & 15 & $180 / 180(100)$ \\
\hline $\mathrm{C} 3 / \mathrm{C} 2$ & 16 & $192 / 192(100)$ & 15 & $180 / 180(100)$ \\
\hline $\mathrm{C} 5 / \mathrm{C} 3$ & 15 & $159 / 165$ (96) & 14 & $168 / 168(100)$ \\
\hline $\mathrm{C} 8 / \mathrm{C} 10$ & 9 & $104 / 108$ (96) & 9 & $108 / 108(100)$ \\
\hline $\mathrm{C} 5 / \mathrm{CO}$ & 10 & $100 / 100(100)$ & 9 & 99/99 (100) \\
\hline $\mathrm{C} 5 / \mathrm{C} 2$ & 14 & $152 / 154$ (99) & 13 & $155 / 156$ (99) \\
\hline $\mathrm{C} 8 / \mathrm{C} 2$ & 16 & 190/192 (99) & 14 & $167 / 168$ (99) \\
\hline
\end{tabular}


Table 6. Results of the proficiency testing of expanded neonatal screening tests using tandem mass spectrometry in 2019

\begin{tabular}{|c|c|c|c|c|}
\hline \multirow[b]{2}{*}{ Variable } & \multicolumn{2}{|c|}{ 1st trial } & \multicolumn{2}{|c|}{ 2nd trial } \\
\hline & $\begin{array}{c}\text { No. of } \\
\text { institutions }\end{array}$ & $\begin{array}{c}\text { Proportion of } \\
\text { correct answers (\%) }\end{array}$ & $\begin{array}{c}\text { No. of } \\
\text { institutions }\end{array}$ & $\begin{array}{c}\text { Proportion of } \\
\text { correct answers (\%) }\end{array}$ \\
\hline \multicolumn{5}{|l|}{ Amino acids } \\
\hline Arginine & 15 & $180 / 180(100)$ & 14 & $168 / 168(100)$ \\
\hline Tyrosine & 15 & $180 / 180(100)$ & 14 & $168 / 168(100)$ \\
\hline Phenylalanine & 15 & $180 / 180(100)$ & 14 & $168 / 168(100)$ \\
\hline Methionine & 15 & $178 / 180$ (99) & 14 & $168 / 168(100)$ \\
\hline Citrulline & 15 & $180 / 180(100)$ & 14 & $168 / 168(100)$ \\
\hline Glycine & 15 & $179 / 180(99)$ & 14 & $168 / 168(100)$ \\
\hline Ornithine & 15 & $180 / 180(100)$ & 14 & $168 / 168(100)$ \\
\hline Valine & 15 & $180 / 180(100)$ & 14 & $168 / 168(100)$ \\
\hline Leucine+isoleucine & 15 & $180 / 180(100)$ & 14 & $168 / 168(100)$ \\
\hline Phenylalanine/tyrosine & 13 & 155/156 (99) & 10 & $120 / 120(100)$ \\
\hline Methionine/phenylalanine & 13 & 155/156 (99) & 10 & $120 / 120(100)$ \\
\hline Alanine & 15 & $180 / 180(100)$ & 14 & $168 / 168(100)$ \\
\hline Histidine & 14 & 165/168 (98) & 12 & 138/144 (96) \\
\hline Proline & 14 & $168 / 168(100)$ & 13 & $156 / 156(100)$ \\
\hline Aspartate & 5 & $58 / 60(97)$ & 3 & $36 / 36(100)$ \\
\hline Glutamate & 8 & $96 / 96(100)$ & 8 & $96 / 96(100)$ \\
\hline \multicolumn{5}{|l|}{ Acylcarnitines } \\
\hline $\mathrm{CO}$ & 15 & $180 / 180(100)$ & 14 & $168 / 168(100)$ \\
\hline $\mathrm{C} 2$ & 15 & $180 / 180(100)$ & 14 & $168 / 168(100)$ \\
\hline $\mathrm{C} 3$ & 15 & $180 / 180(100)$ & 14 & $168 / 168(100)$ \\
\hline C4 & 15 & $180 / 180(100)$ & 14 & $168 / 168(100)$ \\
\hline $\mathrm{C} 5$ & 15 & $180 / 180(100)$ & 14 & $168 / 168(100)$ \\
\hline $\mathrm{C} 6$ & 15 & $180 / 180(100)$ & 14 & $168 / 168(100)$ \\
\hline $\mathrm{C} 8$ & 15 & $180 / 180(100)$ & 14 & $168 / 168(100)$ \\
\hline $\mathrm{C} 10$ & 15 & $180 / 180(100)$ & 14 & $168 / 168(100)$ \\
\hline $\mathrm{C} 12$ & 15 & 178/180 (99) & 14 & $168 / 168(100)$ \\
\hline C14 & 15 & 179/180 (99) & 14 & $168 / 168(100)$ \\
\hline $\mathrm{C} 16$ & 15 & $180 / 180(100)$ & 14 & $168 / 168(100)$ \\
\hline C18 & 15 & $180 / 180(100)$ & 14 & $168 / 168(100)$ \\
\hline C5DC & 15 & 177/180 (98) & 13 & $156 / 156(100)$ \\
\hline $\mathrm{C} 5-\mathrm{OH}$ & 14 & $165 / 168$ (98) & 12 & $144 / 144(100)$ \\
\hline $\mathrm{C} 3 / \mathrm{C} 2$ & 13 & $156 / 156(100)$ & 10 & $120 / 120(100)$ \\
\hline $\mathrm{C} 5 / \mathrm{C} 3$ & 11 & $132 / 132(100)$ & 9 & $108 / 108(100)$ \\
\hline C8/C10 & 7 & 82/84 (98) & 6 & $72 / 72(100)$ \\
\hline $\mathrm{C} 5 / \mathrm{CO}$ & 8 & 96/96 (100) & 6 & $72 / 72(100)$ \\
\hline $\mathrm{C} 5 / \mathrm{C2}$ & 12 & $142 / 144$ (99) & 9 & $108 / 108(100)$ \\
\hline $\mathrm{C} 8 / \mathrm{C} 2$ & 12 & $142 / 144$ (99) & 9 & $108 / 108(100)$ \\
\hline
\end{tabular}


래하였다.

$\mathrm{MS} / \mathrm{MS}$ 검사상 포함된 각 항목에 대한 판정기준치의 분포는 Table 4와 같았으며, 항목별 정답률 현황은 Table 5와 Table 6에 정리하였다. 신생아선별검사에 대해서는 모든 검사항목별로 각 기 관들에서 보고한 결과 수치와 해당 판정기준치를 상대적으로 비교 가능하도록 그래프로 제공하였다. 각 기관별로 결과보고하는 검사 항목이 다소 차이가 있으며, 결과판정에 사용하는 항목별 기준치 는 상당히 차이가 큰 것으로 확인되었다. 판정기준치 주변의 농도 를 갖는 검체에 대해서는 판정일치율이 낮아 결과분석에서는 제외 처리하였다.

요중MMA 및 VMA에 대한 신빙도조사 결과는 Table 7 , 카테콜 라민과 메타네프린 검사결과는 Table 8 및 Table 9에 제시하였
다. 이 항목들은 매년 5-7기관이 신빙도조사에 참여하므로 표준 편차나 변이계수 등의 통계지표를 산출하지는 않으나, 보고된 결 과값들의 분포와 중앙값, 최소 및 최대값을 확인할 수 있도록 하였 다.

아미노산 분석결과는 Table 10 , 유기산 분석결과는 Table 11 에 제시하였다. 아미노산이나 유기산검사의 경우 해당 대사이상질 환에 대한 전형적인 양상을 보이는 검체들에 대해서는 모든 기관 에서 보고한 진단명이 일치하였다. 그러나 양성으로 보고한 대상 성분들의 수치결과를 보면, 그 상승 정도는 기관별로 상당한 차이 를 보이는 경우가 있었다.

Table 7. Proficiency testing results for methylmalonic acid and vanillylmandelic acid

\begin{tabular}{|c|c|c|c|c|c|c|}
\hline Variable & Trial & Specimen no. & No. & Median & Minimum & Maximum \\
\hline \multicolumn{7}{|c|}{ Methylmalonic acid (mg/L) } \\
\hline \multirow[t]{6}{*}{2018} & 1 st & CMM-18-01 & 5 & 1.00 & 1.00 & 1.00 \\
\hline & & CMM-18-02 & & 5.00 & 5.00 & 6.00 \\
\hline & & CMM-18-03 & & 13.00 & 12.00 & 18.00 \\
\hline & 2nd & CMM-18-04 & 4 & 29.50 & 24.10 & 36.90 \\
\hline & & CMM-18-05 & & 1.00 & 0.70 & 1.10 \\
\hline & & CMM-18-06 & & 10.30 & 8.40 & 12.50 \\
\hline \multirow[t]{6}{*}{2019} & $1 s t$ & CMM-19-01 & 4 & 15.10 & 14.80 & 15.50 \\
\hline & & CMM-19-02 & & 1.00 & 0.90 & 1.00 \\
\hline & & CMM-19-03 & & 26.10 & 24.40 & 26.70 \\
\hline & 2nd & CMM-19-04 & 4 & 4.20 & 4.00 & 4.30 \\
\hline & & CMM-19-05 & & 25.40 & 22.90 & 27.80 \\
\hline & & CMM-19-06 & & 11.70 & 10.90 & 13.50 \\
\hline \multicolumn{7}{|c|}{ Vannillymandelic acid (mg/L) } \\
\hline \multirow[t]{6}{*}{2018} & 1 st & CMV-18-01 & 7 & 5.00 & 5.00 & 6.00 \\
\hline & & CMV-18-02 & & 11.00 & 10.00 & 11.00 \\
\hline & & CMV-18-03 & & 21.00 & 19.00 & 22.00 \\
\hline & 2nd & CMV-18-04 & 6 & 15.20 & 13.70 & 15.70 \\
\hline & & CMV-18-05 & & 3.00 & 2.90 & 3.30 \\
\hline & & CMV-18-06 & & 45.00 & 37.40 & 50.50 \\
\hline \multirow[t]{6}{*}{2019} & $1 \mathrm{st}$ & CMV-19-01 & 7 & 47.90 & 42.90 & 50.80 \\
\hline & & CMV-19-02 & & 3.30 & 2.50 & 3.50 \\
\hline & & CMV-19-03 & & 9.70 & 9.30 & 10.90 \\
\hline & $2 n d$ & CMV-19-04 & 7 & 47.40 & 42.30 & 50.60 \\
\hline & & CMV-19-05 & & 4.80 & 4.70 & 5.40 \\
\hline & & CMV-19-06 & & 9.90 & 9.20 & 10.70 \\
\hline
\end{tabular}


Table 8. Proficiency testing results for catecholamines

\begin{tabular}{|c|c|c|c|c|c|c|c|}
\hline Variable & Year & Trial & Specimen no. & No. & Median & Minimum & Maximum \\
\hline \multicolumn{8}{|c|}{ Catecholamines, plasma (pg/mL) } \\
\hline \multirow[t]{12}{*}{ Dopamine } & 2018 & $1 \mathrm{st}$ & CMCP-18-01 & 6 & 390.0 & 311.0 & 455.0 \\
\hline & & & CMCP-18-02 & & 80.0 & 53.0 & 166.0 \\
\hline & & & CMCP-18-03 & & 220.0 & 190.0 & 391.0 \\
\hline & & 2nd & CMCP-18-04 & 5 & 79.00 & 78.50 & 132.60 \\
\hline & & & CMCP-18-05 & & 394.20 & 341.00 & 485.50 \\
\hline & & & CMCP-18-06 & & 29.80 & 0.00 & 64.20 \\
\hline & 2019 & 1 st & CMCP-19-01 & 6 & 320.2 & 306.2 & 540.4 \\
\hline & & & CMCP-19-02 & & 177.7 & 135.5 & 317.0 \\
\hline & & & CMCP-19-03 & & 65.6 & 23.5 & 95.6 \\
\hline & & 2nd & CMCP-19-04 & 5 & 673.9 & 478.8 & 700.0 \\
\hline & & & CMCP-19-05 & & 832.8 & 693.5 & 977.2 \\
\hline & & & CMCP-19-06 & & 347.0 & 227.3 & 365.8 \\
\hline \multirow[t]{12}{*}{ Epinephrine } & 2018 & 1 st & CMCP-18-01 & 6 & 1040.0 & 965.0 & 1337.0 \\
\hline & & & CMCP-18-02 & & 66.0 & 62.0 & 93.0 \\
\hline & & & CMCP-18-03 & & 536.0 & 515.0 & 756.0 \\
\hline & & 2nd & CMCP-18-04 & 6 & 94.0 & 67.0 & 114.7 \\
\hline & & & CMCP-18-05 & & 1389.7 & 969.0 & 1537.5 \\
\hline & & & СМСР-18-06 & & 24.8 & 0.0 & 56.0 \\
\hline & 2019 & $1 \mathrm{st}$ & СМCP-19-01 & 7 & 1099.0 & 893.2 & 1462.0 \\
\hline & & & CMCP-19-02 & & 587.4 & 414.3 & 836.2 \\
\hline & & & CMCP-19-03 & & 81.1 & 57.7 & 118.7 \\
\hline & & 2nd & CMCP-19-04 & 6 & 373.0 & 284.7 & 383.0 \\
\hline & & & СMCP-19-05 & & 600.0 & 527.3 & 645.0 \\
\hline & & & СМСР-19-06 & & 116.4 & 72.4 & 131.1 \\
\hline \multirow[t]{12}{*}{ Norepinephrine } & 2018 & $1 \mathrm{st}$ & CMCP-18-01 & 6 & 1253.0 & 1215.0 & 1493.0 \\
\hline & & & CMCP-18-02 & & 281.0 & 249.0 & 311.0 \\
\hline & & & CMCP-18-03 & & 788.0 & 688.0 & 859.0 \\
\hline & & 2nd & CMCP-18-04 & 6 & 317.5 & 280.0 & 349.0 \\
\hline & & & СМCP-18-05 & & 1312.4 & 1156.0 & 1488.1 \\
\hline & & & СMCP-18-06 & & 28.0 & 0.0 & 37.0 \\
\hline & 2019 & 1 st & СМСР-19-01 & 7 & 1223.8 & 1152.1 & 1541.6 \\
\hline & & & СMCP-19-02 & & 744.3 & 618.0 & 1013.0 \\
\hline & & & СМСР-19-03 & & 283.4 & 248.8 & 395.4 \\
\hline & & 2nd & СМСР-19-04 & 6 & 1151.2 & 1063.3 & 1253.0 \\
\hline & & & СМCP-19-05 & & 2028.3 & 1785.3 & 2134.0 \\
\hline & & & CMCP-19-06 & & 302.4 & 279.5 & 316.7 \\
\hline
\end{tabular}


Table 8. Continued

\begin{tabular}{|c|c|c|c|c|c|c|c|}
\hline Variable & Year & Trial & Specimen no. & No. & Median & Minimum & Maximum \\
\hline \multicolumn{8}{|c|}{ Catecholamines, urine $(\mathrm{ng} / \mathrm{mL})$} \\
\hline \multirow[t]{12}{*}{ Dopamine } & 2018 & $1 s t$ & CMU-18-01 & 8 & 79.0 & 72.0 & 189.0 \\
\hline & & & CMU-18-02 & & 80.0 & 77.0 & 143.0 \\
\hline & & & CMU-18-03 & & 487.0 & 363.0 & 565.0 \\
\hline & & 2nd & CMU-18-04 & 6 & 70.7 & 60.5 & 77.7 \\
\hline & & & CMU-18-05 & & 414.6 & 350.6 & 511.8 \\
\hline & & & CMU-18-06 & & 700.1 & 658.6 & 784.6 \\
\hline & 2019 & 1 st & CMU-19-01 & 7 & 716.6 & 672.9 & 816.8 \\
\hline & & & CMU-19-02 & & 416.5 & 370.8 & 441.4 \\
\hline & & & CMU-19-03 & & 73.0 & 63.1 & 90.9 \\
\hline & & 2nd & CMU-19-04 & 6 & 405.4 & 383.9 & 422.0 \\
\hline & & & CMU-19-05 & & 73.8 & 62.9 & 79.2 \\
\hline & & & CMU-19-06 & & 708.6 & 613.9 & 769.3 \\
\hline \multirow[t]{12}{*}{ Epinephrine } & 2018 & 1 st & CMU-18-01 & 8 & 14.0 & 13.0 & 28.0 \\
\hline & & & CMU-18-02 & & 14.0 & 12.0 & 24.0 \\
\hline & & & CMU-18-03 & & 82.0 & 69.0 & 98.0 \\
\hline & & 2nd & CMU-18-04 & 6 & 12.0 & 10.5 & 13.7 \\
\hline & & & CMU-18-05 & & 77.9 & 62.5 & 86.5 \\
\hline & & & CMU-18-06 & & 130.7 & 105.1 & 141.4 \\
\hline & 2019 & $1 s t$ & CMU-19-01 & 7 & 110.3 & 89.8 & 132.6 \\
\hline & & & CMU-19-02 & & 69.9 & 57.3 & 75.5 \\
\hline & & & CMU-19-03 & & 13.6 & 10.5 & 14.5 \\
\hline & & 2nd & CMU-19-04 & 6 & 64.0 & 60.7 & 71.6 \\
\hline & & & CMU-19-05 & & 12.3 & 10.9 & 14.0 \\
\hline & & & CMU-19-06 & & 111.8 & 92.8 & 125.4 \\
\hline \multirow[t]{12}{*}{ Norepinephrine } & 2018 & 1 st & CMU-18-01 & 8 & 45.0 & 42.0 & 76.0 \\
\hline & & & CMU-18-02 & & 45.0 & 42.0 & 112.0 \\
\hline & & & CMU-18-03 & & 202.0 & 175.0 & 216.0 \\
\hline & & 2nd & CMU-18-04 & 6 & 40.4 & 36.8 & 43.2 \\
\hline & & & CMU-18-05 & & 182.7 & 167.1 & 200.6 \\
\hline & & & CMU-18-06 & & 294.1 & 284.3 & 329.9 \\
\hline & 2019 & 1 st & CMU-19-01 & 7 & 299.8 & 266.6 & 325.1 \\
\hline & & & CMU-19-02 & & 166.5 & 156.8 & 180.5 \\
\hline & & & CMU-19-03 & & 41.5 & 36.7 & 45.0 \\
\hline & & 2nd & CMU-19-04 & 6 & 166.7 & 159.5 & 170.9 \\
\hline & & & CMU-19-05 & & 41.6 & 39.2 & 45.3 \\
\hline & & & CMU-19-06 & & 296.5 & 280.4 & 326.9 \\
\hline
\end{tabular}


Table 9. Proficiency testing results for metanephrines

\begin{tabular}{|c|c|c|c|c|c|c|c|}
\hline Variable & Year & Trial & Specimen no. & No. & Median & Minimum & Maximum \\
\hline \multicolumn{8}{|c|}{ Metanephrines, plasma (nmol/L) } \\
\hline \multirow[t]{12}{*}{ Metanephrine } & 2018 & $1 \mathrm{st}$ & CMMP-16-01 & 6 & 0.00 & 0.00 & 1.00 \\
\hline & & & CMMP-16-02 & & 4.00 & 3.00 & 4.00 \\
\hline & & & CMMP-16-03 & & 2.00 & 2.00 & 2.00 \\
\hline & & $2 n d$ & CMMP-16-04 & 5 & 0.12 & 0.01 & 1.97 \\
\hline & & & CMMP-16-05 & & 1.14 & 1.11 & 1.56 \\
\hline & & & CMMP-16-06 & & 2.36 & 2.23 & 3.03 \\
\hline & 2019 & $1 s t$ & CMMP-17-01 & 6 & 0.16 & 0.03 & 1.96 \\
\hline & & & CMMP-17-02 & & 2.16 & 1.86 & 3.85 \\
\hline & & & CMMP-17-03 & & 1.11 & 1.03 & 3.37 \\
\hline & & 2nd & CMMP-17-04 & 6 & 0.17 & 0.14 & 1.33 \\
\hline & & & CMMP-17-05 & & 1.24 & 1.17 & 8.71 \\
\hline & & & CMMP-17-06 & & 0.75 & 0.71 & 5.28 \\
\hline \multirow[t]{12}{*}{ Normaetanephrine } & 2018 & $1 \mathrm{st}$ & CMMP-16-01 & 6 & 1.00 & 1.00 & 2.00 \\
\hline & & & CMMP-16-02 & & 19.00 & 16.00 & 21.00 \\
\hline & & & CMMP-16-03 & & 10.00 & 8.00 & 11.00 \\
\hline & & $2 n d$ & CMMP-16-04 & 5 & 0.37 & 0.17 & 4.47 \\
\hline & & & CMMP-16-05 & & 3.73 & 3.56 & 4.75 \\
\hline & & & CMMP-16-06 & & 7.65 & 7.55 & 8.66 \\
\hline & 2019 & $1 s t$ & CMMP-17-01 & 6 & 0.35 & 0.18 & 3.90 \\
\hline & & & CMMP-17-02 & & 10.43 & 9.68 & 13.41 \\
\hline & & & CMMP-17-03 & & 5.34 & 4.91 & 9.78 \\
\hline & & 2nd & CMMP-17-04 & 6 & 0.38 & 0.35 & 2.83 \\
\hline & & & CMMP-17-05 & & 4.78 & 4.50 & 30.59 \\
\hline & & & CMMP-17-06 & & 2.66 & 2.49 & 18.25 \\
\hline \multicolumn{8}{|c|}{ Metanephrines, urine (ng/mL) } \\
\hline \multirow[t]{12}{*}{ Metanephrine } & 2018 & 1 st & CMU-16-01 & 7 & 104.0 & 95.0 & 109.0 \\
\hline & & & CMU-16-02 & & 103.0 & 95.0 & 112.0 \\
\hline & & & CMU-16-03 & & 522.0 & 499.0 & 540.0 \\
\hline & & 2nd & CMU-16-04 & 6 & 91.8 & 74.4 & 99.1 \\
\hline & & & CMU-16-05 & & 473.8 & 436.5 & 508.6 \\
\hline & & & CMU-16-06 & & 741.0 & 662.4 & 776.0 \\
\hline & 2019 & $1 \mathrm{st}$ & CMU-17-01 & 7 & 774.9 & 717.3 & 885.9 \\
\hline & & & CMU-17-02 & & 461.5 & 438.4 & 485.0 \\
\hline & & & CMU-17-03 & & 92.9 & 90.7 & 99.3 \\
\hline & & 2nd & CMU-17-04 & 7 & 457.0 & 424.3 & 516.7 \\
\hline & & & CMU-17-05 & & 96.3 & 86.5 & 110.0 \\
\hline & & & CMU-17-06 & & 778.0 & 659.4 & 818.8 \\
\hline
\end{tabular}


Table 9. Continued

\begin{tabular}{|c|c|c|c|c|c|c|c|}
\hline Variable & Year & Trial & Specimen no. & No. & Median & Minimum & Maximum \\
\hline \multirow[t]{12}{*}{ Normaetanephrine } & 2018 & $1 s t$ & CMU-16-01 & 7 & 323.0 & 306.0 & 340.0 \\
\hline & & & CMU-16-02 & & 324.0 & 308.0 & 334.0 \\
\hline & & & CMU-16-03 & & 1374.0 & 1317.0 & 1497.0 \\
\hline & & 2nd & CMU-16-04 & 6 & 314.3 & 273.3 & 319.0 \\
\hline & & & CMU-16-05 & & 1342.5 & 1168.5 & 1392.8 \\
\hline & & & CMU-16-06 & & 2168.0 & 1959.0 & 2287.2 \\
\hline & 2019 & $1 s t$ & CMU-17-01 & 7 & 2164.8 & 2069.0 & 2291.3 \\
\hline & & & CMU-17-02 & & 1260.9 & 1161.9 & 1325.0 \\
\hline & & & CMU-17-03 & & 314.0 & 297.1 & 346.7 \\
\hline & & 2nd & CMU-17-04 & 7 & 1172.6 & 1122.0 & 1286.0 \\
\hline & & & CMU-17-05 & & 312.0 & 286.0 & 358.6 \\
\hline & & & CMU-17-06 & & 2100.0 & 1835.2 & 2179.7 \\
\hline
\end{tabular}

\section{고찰}

선천성 대사이상질환 조기발견을 위한 신생아선별검사 대상 신 빙도조사사업은 1997년에 처음 시행되었으며, 2002년도부터는 매년 2회씩 시행되고 있다. MS/MS를 이용한 광범위선별검사에 대한 신빙도조사사업은 2007년도부터 시작하였고, 2011년도부 터는 아미노산, 유기산, MMA, VMA 등을 포함하여 종목 확대를 위 한 노력이 계속되었다. 2014년도에는 요중 카테콜라민, 메타네프 린 종목을, 2016년도부터는 혈중 카테콜라민 및 메타네프린 종목 까지 추가되었다. 정도관리 검체는 상품화된 정도관리 검체와 자 가제조 검체를 혼용하여 사용해 왔는데, 정상과 비정상 수치, 판정 기준치 주변 수치가 모두 포함되도록 하기 위해 자가제조 검체의 비중을 점차 더욱 높이게 되었다.

특히 신생아선별검사의 경우, 각 항목별 검체의 수를 증가시키 고 판정기준치보다 경미한 상승수치를 보이는 검체까지도 포함시 키므로써 신빙도조사를 통한 각 기관의 검사수행능 및 문제점을 보다 정확히 파악하고 개선하는 데 도움을 주고자 하였다. 그 결 과, 판정의 불일치를 보인 항목들이 일부 항목들 또는 일부 기관에 서 발견되었다. 판정 불일치를 보인 기관들은 판정기준치 주변 수 치를 보이는 검체에 대해 판정기준치는 타기관과 별로 차이가 없 으면서 수치결과가 타기관에 비해 차이를 보이거나, 수치결과는 비슷하지만 해당기관에서 이용 중인 판정기준치가 타기관과 차이 가 있어 최종 판정이 달라지는 경우였다. 기본 신생아선별검사 종 목과 $\mathrm{MS} / \mathrm{MS}$ 를 이용한 광범위선별검사에 대한 결과판정 시, 결과 를 보고한 기관들에서 $80 \%$ 이상의 일치를 보이는 결과를 의도된 정답으로 간주하였고, 기관 간 일치율이 낮은 경우와 검체 이상이
의심되는 경우 등에 대해서는 판정 보류대상으로 결정하였다.

기본 6종 검사 중 $\mathrm{MS} / \mathrm{MS}$ 로 검사가 가능한 3가지 항목들에 대 해서는 수년 전부터 페닐케톤뇨증검사만을 면역분석법으로 시행 하는 1 개 기관을 제외하고는 모두 MS/MS 검사법이 활용되고 있 으며 검사의 일치율이 높았다. T4나 TSH항목의 경우에는 다양한 종류의 정도관리물질 확보가 힘들며 기관별 검사방법이 달라 항 상 어려움을 겪는데, 특히 판정기준치에 인접한 측정값을 나타내 는 항목들은 결과 판정일치율이 낮아 판정 보류로 결정한 항목들 이 있었다. 이러한 검체들에 대한 분석결과들에 대해서는 기관별 측정값, 측정방법, 판정기준치의 차이와 그에 따른 판정결과의 차 이, 재검율에 대해 각 기관 자체적으로 면밀한 고찰이 필요하겠다. 특히 대부분의 기관에서 선별검사 양성으로 보고한 비정상 검체에 대해 위음성 결과를 보인다면 문제가 될 수 있다. 선천성갑상선기 능저하증 선별검사로 total T4가 아닌 free T4검사를 시행하는 기 관은 2019년에 들어서는 1 개 기관으로 줄어들어, 타기관과의 비 교평가나 결과 적정성 판정이 불가능하므로 본 신빙도조사의 참 여가 실질적인 도움이 되지 않을 것으로 판단되어 검사법 재검토 를 권유하기도 하였다. 보험정책 변화에 따라 2019년부터는 기본 6종 선별검사와 광범위선별검사가 통합된 상황이므로, 향후에는 $\mathrm{PKU}, \mathrm{MSUD}, \mathrm{HCY}$ 의 경우 $\mathrm{MS} / \mathrm{MS}$ 검사 쪽으로 포함시켜 분류하 여야 할 것으로 보인다.

$\mathrm{MS} / \mathrm{MS}$ 를 이용한 광범위선별검사는 수십 종의 항목을 동시에 분석하고 관련 성분들과 해당 질환에서의 증감 양상 등을 고려하 셔 종합적으로 판정하는 검사이기 때문에 개별 성분의 수치값 자 체가 절대적으로 중요한 것은 아니다. 또한 표준화된 검사가 아니 라 각 기관에서 사용하는 장비와 시약, 분석조건이 달라 얻어지는 


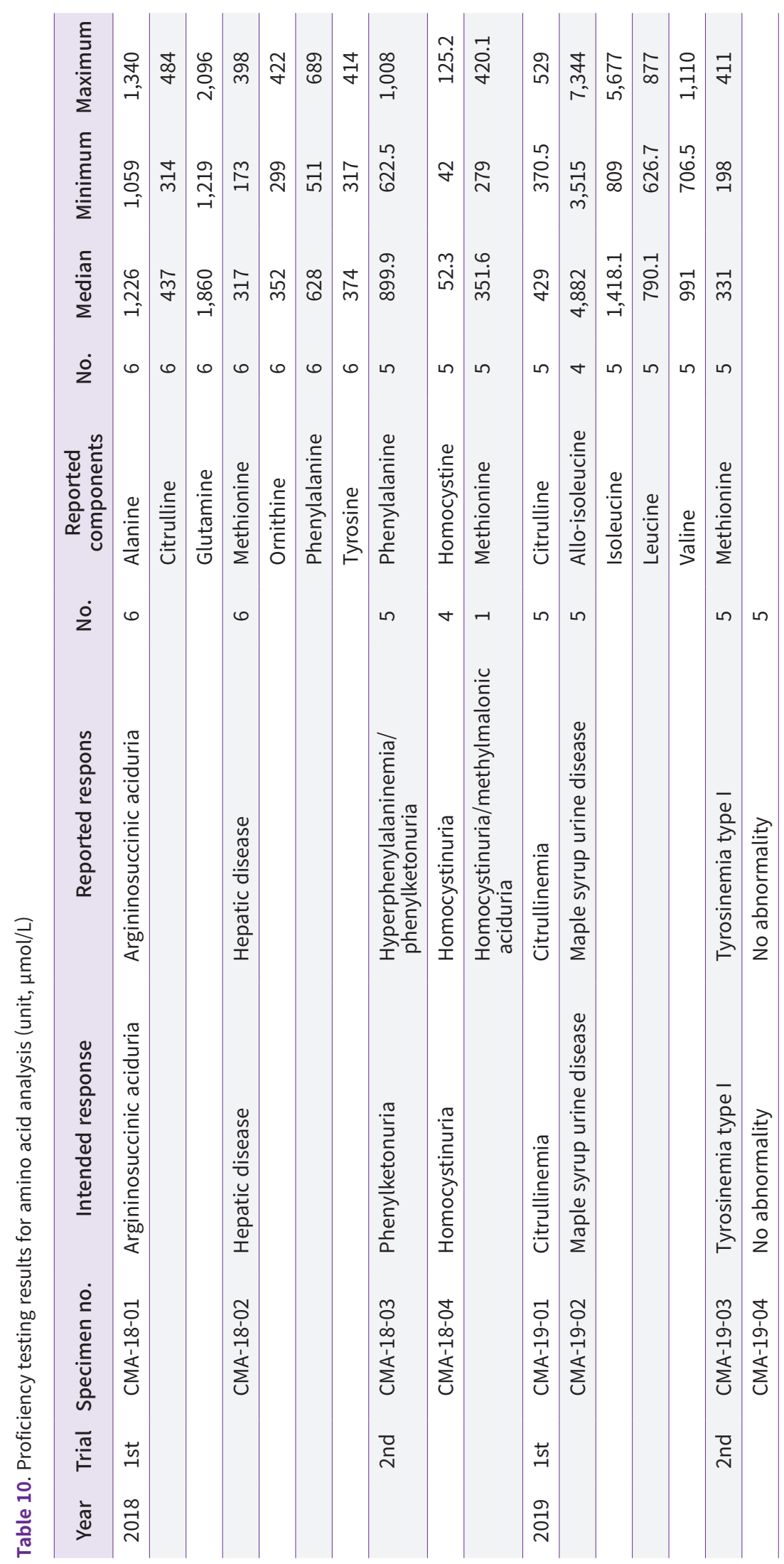




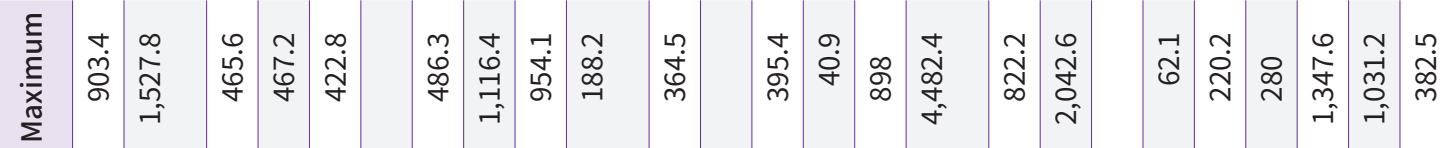

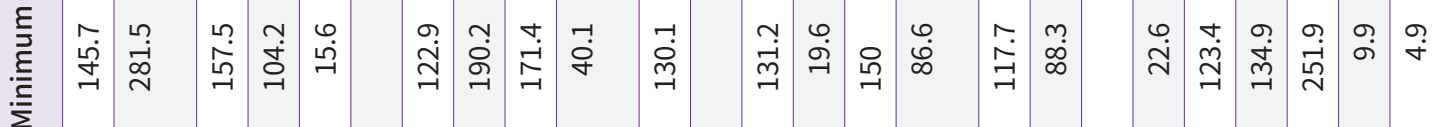

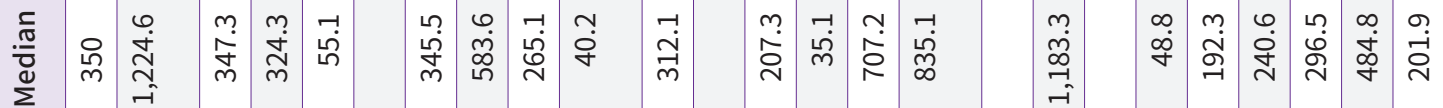

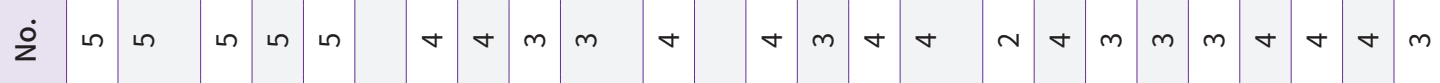

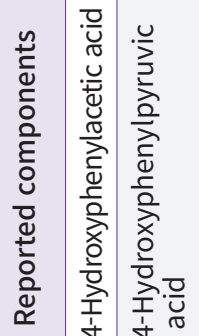

$\frac{\sqrt{2}}{\sqrt{\frac{0}{0}}}$

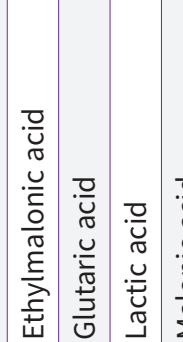

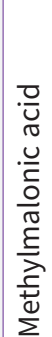

$\frac{\overline{0}}{\overline{0}}$

$\dot{\mathrm{z}}$ in
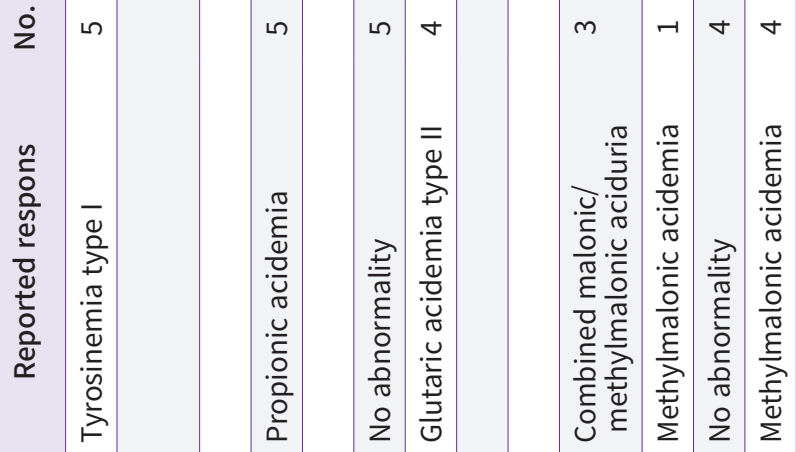

mat

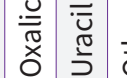

产

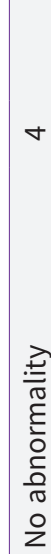

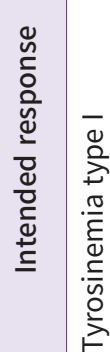
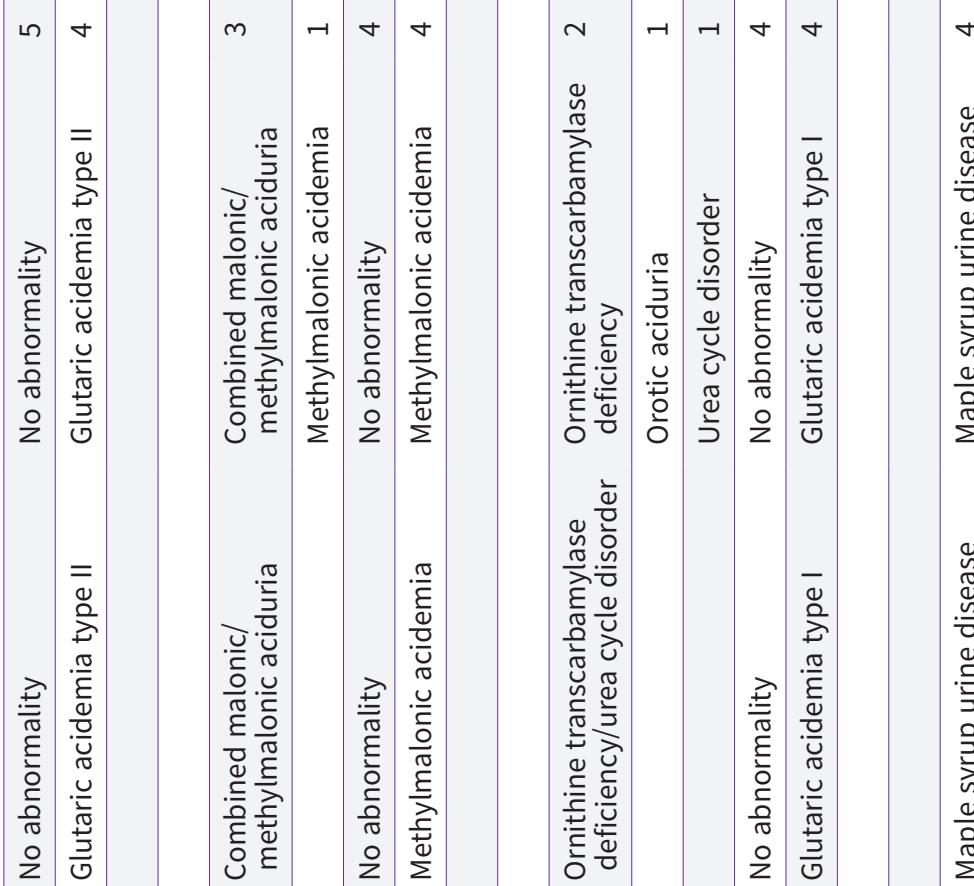

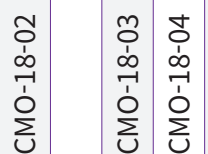

눙

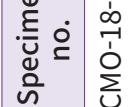

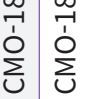

우요

票

文

宅

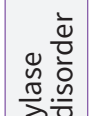

हो

离命

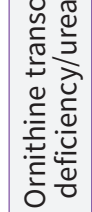

บั

꼰
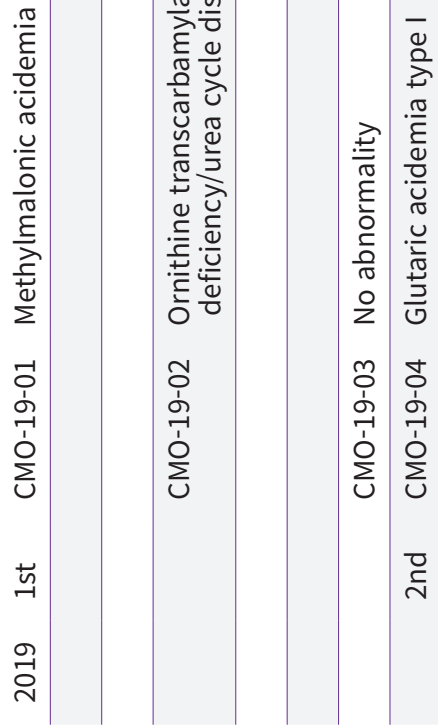
결과 수치도 차이를 보일 수 있고, 해당 기관의 검사자료를 기반으 로 자체적으로 설정한 판정기준치를 활용해 이상결과 여부를 판 정하게 된다. 2017년도부터는 정도관리협회 방침에 따라 수치결 과에 대한 상세 통계분석결과도 제공되었는데, 본 신빙도조사에서 수치결과는 최종 판정대상이 아니며 참고자료로서 이용하면 도움 이 될 수도 있다. 광범위선별검사에서도 개별 종목별로 보면 일부 종목에서 판정 불일치가 관찰되었으며, 이들 기관에서는 자체적 으로 기관 내 판정기준치 및 검사방법에 대한 검토 후 필요 시 조 치할 것이 권장된다. 특정 종목에서 반복적으로 판정 불일치를 보 이는 경우라든가 판정기준치가 타기관에 비해 유의하게 다른 경 우에는 전체 검사결과에 대한 분포 그래프를 타기관들과 비교하 면서 살펴보는 것이 도움이 될 것이다. 신빙도 사에서 나타난 바와 같이 현재 각 기관들에서 사용 중인 판정기준치 수치는 종목에 따 라 2 배 이상 차이를 보이는 경우가 흔하다. 기관 자체적으로 주기 적인 판정기준치 검증을 시행하는 것이 필수적인 사항이며, 본 신 빙도조사 결과분석 자료를 타기관과의 판정기준치 차이, 검사결 과 수치 분포의 차이를 파악하는 데 활용하면 되겠다. 또한 MS/ $\mathrm{MS}$ 검사에서 일부 항목들에 대하여 보고하지 않는 기관의 경우 자 체적인 검토를 통하여 보고 항목으로 추가를 검토할 것이 권장된 다. 관련 성분의 상대적 비율을 관찰하면 진단의 정확성을 향상시 키는 데 도움이 되며, 신빙도조사 결과에 따르면 phenylalanine/ tyrosine과 $\mathrm{C} 3 / \mathrm{C} 2$ 비율 등 주요 항목은 현재 모든 기관에서 적용 하고 있는 것으로 나타났다.

유기산검사는 각 회차별 2검체씩을 발송해 오다가 2017년 2 차 시기부터 3검체씩으로 증가시켰으며, 질환명과 판정기준치 이 상의 증가를 보이는 유기산들을 보고하도록 하였다. Propionic acidemia, MSUD, glutaric aciduria, PKU와 같은 전형적인 증 감 양상을 보이는 검체와 정상인 검체, 그리고 urea cycle defect 의 진단 및 감별진단을 위한 orotic acid의 검출을 요하는 검체도 포함되었다. 원래 검체 제조 시 의도한 질환명을 정답으로 간주하 였는데, 거의 모든 기관에서 합당한 질환명을 정확하게 제시하였 다. 하지만 해당 검출물질에 대한 상승 정도는 10 배 이상까지 기 관별로 상당한 농도의 차이를 보였고 증가한 것으로 보고한 검출 성분이 다소 차이를 보이는 경우도 있었다. 다만 제조 시 양성으로 의도한 성분이 검출되지 않거나 다른 농도를 보인 경우도 있는데, 검체운송이나 취급상의 문제일 가능성을 완전히 배제할 수 없으 나, 유기산검사법의 차이, 분석결과 확인 및 해석상의 문제가 없는 지 재검토할 필요도 있겠다.

아미노산검사는 회차별 2개 검체를 발송하였다. 2016년 신빙 도조사부터는 각 기관이 제출한 최종 결과해석을 중심으로 판정하 고 있다. 유기산검사와 마찬가지로 원래 검체 제조 시 의도한 질환 명을 정답으로 간주하였는데, 해당 대사이상질환에 대한 전형적인
양상을 보이는 검체들에 대해서는 모든 기관에서 보고한 진단명이 일치하였다. 양성으로 보고한 아미노산 성분들의 수치결과를 보 면, 그 상승 정도는 기관별로 2-5배 정도까지 차이를 보인 경우가 있었다.

$\mathrm{MMA}, \mathrm{VMA}$ 항목의 경우 매 회차마다 각각 4-5기관, 6-7기관 이 참여하였다. 다른 종목들에 비하면 모든 기관에서 비교적 유사 한 측정결과값을 보고하였는데, 이는 상품화된 보정물질 및 키트 의 사용에 기인한 것으로 생각되었다. 혈중 및 요중 카테콜라민과 요중 메타네프린 항목은 응답한 모든 기관에서 비교적 유사한 측 정결과값을 보고하였다. 단, 실제 임상검사에서는 카테콜라민과 메타네프린이 무작위뇨가 아닌 24시간 요를 대상으로 하기 때문 에 요수집의 적정성이 검사결과에 영향을 미치는 다른 변수가 될 것이고, 본 신빙도조사에서는 최종 보고결과와 참고치는 비교해 볼 수는 없는 한계점이 있다. 혈중 메타네프린은 일부 기관에서 보 고결과 수치가 타기관과 상당한 차이를 보인 경우도 있었는데, 검 사대상인 혈중농도 자체가 낮은 범위에 있고 검사가 표준화되지 않았으며, 검체안정성의 문제도 배제할 수 없으나, 진단의 판정기 준치 자체는 기존 문헌 자료를 바탕으로 대부분의 기관에서 비슷 한 수치를 적용하고 있을 것으로 생각되므로 각 기관에서는 본 신 빙도조사를 참고하되 반드시 자체적으로 분석적 및 임상적 검증을 시행하여야 하겠다. 또한 물질의 안정성 문제를 고려하여 신빙도 조사용 물질을 수령한 이후 검체의 취급과 보관조건을 엄격히 지 켜 분석 전 오류(prenalaytical error)가 발생하지 않도록 유의하 여야 할 것이다.

선천성대사이상질환 조기진단을 위한 신생아선별검사는 검사 수치뿐 아니라 결과에 대한 정상 및 비정상에 대한 적절한 판독이 매우 중요하다. 그러나 각 기관에서 검사에 사용하는 시약과 검사 방법이 다양하고 정상 및 비정상을 평가할 기준치가 서로 다른 경 우가 많았다. 또한 본 신빙도조사에서 겪는 애로사항으로 동일검 사법 이용기관의 수가 적은 경우 비교 불가한 점, 다양한 질환 양 성 검체를 대량 확보하기 어려운 점, 단일 성분만이 아닌 다수의 증감 양상이 조합된 검체를 준비해야 하는 점 등이 있었다. 아미노 산이나 유기산은 대사이상질환의 확진에 중요하므로 주요 성분의 검출과 적절한 결과해석이 이루어지도록 검사를 시행하는 소수의 기관에서는 각별한 주의를 기울여야 하겠다. 검사의 특성을 고려 한 내부정도관리 프로그램의 마련과 운영, 검사자 교육, 장비관리, 그리고 판독의사의 전문성이 필수적으로 요구됨은 물론이고 특수 대사산물의 경우 최근 검사에 대한 관심과 요구도가 높아지고 있 으며 앞으로 시행기관이 더 늘어날 것으로 전망해본다.

각 기관에서는 신빙도조사 결과를 자체적으로도 면밀히 검토 분석하여 분석법의 신뢰성을 확인하고 내부정도관리를 강화함과 동시에 주기적으로 기준치를 검증하고 결과보고 종목 및 결과해석 
의 차이도 점검해보는 것이 매우 중요할 것으로 생각된다. 앞으로 도 종목 확대, 적절한 정도관리물질의 확보, 관련 인력교육을 포함 하여 지속적으로 신빙도조사 프로그램을 개선 및 발전시킬 수 있 는 방향을 모색한다면 검사의 질 향상에 기여할 수 있을 것으로 생 각된다.

\section{감사의 글}

정도관리물질 제조관리와 결과자료정리 등 본 신빙도조사를 위 해 수고해주신 삼성서울병원 진단검사의학과 특수화학검사실 지 옥자 선생님을 비롯한 직원 여러분들과 임상강사 선생님께 감사드 린다.

\section{REFERENCES}

1. Song J, Kwon KC, Kim JH, Kim JW, Min WK, Lee SY, et al. Annual report on external quality assessment in metabolic disorders in Korea (2007). J Lab Med Qual Assur 2008;30:151-66.

2. Lee SY, Kwon KC, Kim JH, Kim JW, Park BT, Park HD, et al. Annual report on external quality assessment in biochemical genetics in Korea (2011). J Lab Med Qual Assur 2012;34:S25-49.

3. Lee SY, Kwon KC, Kim JH, Kim JW, Park BT, Park HD, et al. Annual report on external quality assessment in biochemical genetics in Korea (2012). J Lab Med Qual Assur 2013;35:S29-63.

4. Lee SY; Biochemical Genetics Subcommittee, The Korean Association of Quality Assurance for Clinical Laboratory. Annual report on external quality assessment of biochemical genetics in Korea (2013). J Lab Med Qual Assur 2014;36:64-70.

5. Lee SY, Ji OJ, Kwon GC, Kim JW, Park HD, Song J, et al. Annual report on the external quality assessment scheme for biochemical genetics in Korea (2014). J Lab Med Qual Assur 2015;37:56-63.

6. Lee SY, Ji OJ, Kwon GC, Kim JW, Park HD, Song J, et al. Annual report on the external quality assessment scheme for biochemical genetics in Korea (2015). J Lab Med Qual Assur 2016;38:68-76.

7. Lee SY. Report on the external quality assessment scheme for metabolite testing in Korea (2016-2017). J Lab Med Qual Assur 2018;40:136-48. 